Discussion Paper No. 2002/23

\title{
Can Financial Markets be Tapped to Help Poor People Cope with Weather Risks?
}

\author{
Jerry Skees, ${ }^{1}$ Panos Varangis, 2 \\ Donald Larson ${ }^{2}$ and Paul Siegel 2
}

February 2002

\begin{abstract}
Poor households with little or no wealth are particularly vulnerable to risks that reduce incomes and increase expenditures. This book addresses many of the risk-coping strategies for the rural poor, with a focus on micro level and household actions. Largely, these discussions concern risks that can be shared within a community or extended family. While effective for independent risks, these strategies are rather ineffective for covariate or systemic risks.

This paper focuses on private and public mechanisms for managing such covariate risk for natural disasters. When many households within the same community face risks that create contemporaneous losses for all, the coping mechanisms discussed in other papers in this project are likely to fail. Such covariate risks are not uncommon in many developing countries, especially where farming remains a major source of income. The paper focuses on risks that are related to weather events (excess rain, droughts, freezes, high winds, etc.) that have a severe impact on rural incomes. Weather insurance could cover the covariate risk for a community of poor households through formal and informal risk-sharing arrangement among households that are purchasing these weather contracts. Given some recent Mexican innovations that are targeted at helping the poor cope with catastrophic weather events, we use Mexico as a case study to support some of our general concepts.
\end{abstract}

Keywords: risk management, insurance, weather risks, natural disasters

JEL classification: Q14, G22

\section{Copyright $@$ UNU/WIDER 2002}

${ }^{1}$ Department of Agricultural Economics, University of Kentucky, ${ }^{2}$ Development Research Group, The World Bank

This study has been prepared within the UNU/WIDER project on Insurance Against Poverty, which is directed by Dr Stefan Dercon.

UNU/WIDER gratefully acknowledges the financial contribution to the project by the Ministry for Foreign Affairs of Finland. 


\section{Acknowledgements}

The authors would like to gratefully acknowledge contributions by Paul Siegel and professionals in Mexico who provided information on Mexico and Jonathan Morduch and Stefan Dercon for helpful comments on the paper.

UNU World Institute for Development Economics Research (UNU/WIDER) was established by the United Nations University as its first research and training centre and started work in Helsinki, Finland in 1985. The purpose of the Institute is to undertake applied research and policy analysis on structural changes affecting the developing and transitional economies, to provide a forum for the advocacy of policies leading to robust, equitable and environmentally sustainable growth, and to promote capacity strengthening and training in the field of economic and social policy making. Its work is carried out by staff researchers and visiting scholars in Helsinki and through networks of collaborating scholars and institutions around the world.

UNU World Institute for Development Economics Research (UNU/WIDER)

Katajanokanlaituri 6 B, 00160 Helsinki, Finland

Camera-ready typescript prepared by Jaana Kallioinen at UNU/WIDER

Printed at UNU/WIDER, Helsinki

The views expressed in this publication are those of the author(s). Publication does not imply endorsement by the Institute or the United Nations University, nor by the programme/project sponsors, of any of the views expressed.

ISSN 1609-5774

ISBN 92-9190-164-4 (printed publication)

ISBN 92-9190-165-2 (internet publication) 


\section{Introduction}

Poor households with little or no wealth are particularly vulnerable to risks that reduce incomes and increase expenditures. This project (UNU/WIDER, Insurance Against Poverty) addresses many of the risk-coping strategies for the rural poor, with a focus on micro level and household actions. Largely, these discussions concern risks that can be shared within a community or extended family. While effective for independent risks, these strategies are rather ineffective for covariate or systemic risks.

This paper focuses on private and public mechanisms for managing such covariate risk for natural disasters. When many households within the same community face risks that create contemporaneous losses for all, the coping mechanisms discussed in other papers in this project are likely to fail. Such covariate risks are not uncommon in many developing countries, especially where farming remains a major source of income.

Two sources of covariate risk are common: 1) market risks (prices for output and inputs); and 2) natural disaster risks (hurricanes, droughts, floods, frosts, earthquakes, volcanic eruptions, etc.). While far from perfect, market mechanisms are generally available for managing some market-related risks. For example, even in developing countries, futures exchange markets offer some risk management possibilities for internationally traded commodities. The traditional market-based instrument for managing natural disaster risk, insurance, is largely underdeveloped and unavailable in most parts of the world. Further, insurance alone will not address the problems faced by rural households when natural disasters occur.

This paper focuses on risks that are related to weather events (excess rain, droughts, freezes, high winds, etc.) that have a severe impact on rural incomes. Given the growing interest in weather insurance markets, there are opportunities for innovation that have, as of yet, been largely unexploited. A number of studies are recognizing that markets may more easily provide rainfall insurance than traditional crop insurance in many developing countries (Gautum et al. 1994, Sakurai and Reardon 1997, Skees et al. 1999, and Skees 2000). In addition, we discuss using such parametric insurance to cover covariate risk for a community of poor households through formal and informal risksharing arrangement among households that are purchasing these index contracts. This is a potentially important innovation since instruments for systemic risk can complement the approaches for managing idiosyncratic risks that are described in previous chapters of this volume. Finally, we take our analysis one step further and argue that the basic infrastructure and contracts that are needed to index and insure catastrophic weather events can also be used to support emergency disaster assistance in developing countries.

Given some recent Mexican innovations that are targeted at helping the poor cope with catastrophic weather events, we use Mexico as a case study to support some of our general concepts. Mexico has a couple of unique institutional innovations that could be combined with well-crafted weather indexes that use new developments in the international financial markets. Not only could such indexes be developed to offer insurance to the rural poor, but the same indexes can be crafted to allow improvized governments unique opportunities to hedge budgetary exposure when they provide free disaster aid to the poor. However, we also raise questions about the design of these assistance programmes and the level of assistance since such assistance can provide perverse incentives and many times have unintended consequences. 
We assume that the goal of government intervention after a natural disaster is to provide the most cost effective form of government aid that will help the rural poor. This aid should be provided in an objective fashion with ex ante rules for when and how much assistance to provide. Further, the assistance should not unduly distort economic incentives. In particular, care should be taken to assure that aid does not spur unsustainable new economic activity in areas that are more risky or vulnerable to natural disaster risk. Doing so will likely result in more losses and suffering when the next disaster strikes. Finally, there are alternative ways of structuring such aid so that it facilitates rather than crowds out international and domestic risk.

We argue that government should define disaster and catastrophe within the context of frequency as well as severity. For example, it would be a mistake and very expensive to have government intervention too frequently. The infrequent events that create serious problems may require some level of government intervention, such as free disaster aid. Those events that are more frequent but still cause serious losses may be more appropriately left to private sector insurance markets if the transaction costs of such insurance can be contained. Our solutions involve segmenting and layering the natural disaster risk so that the most catastrophic risk is handled with government aid and the less catastrophic risk is left to market mechanisms.

\section{Risk and the rural poor}

Siegel and Alwang (1999) develop a taxonomy of risk-coping strategies for rural households facing risk and several papers of this WIDER project explore these strategies in greater detail. However, as mentioned, many strategies are unavailable or prove ineffective for the poor, especially when the risks are covariate. Households living on very low incomes and limited wealth become highly risk adverse since even a small disruption in income flows can have devastating effects. Such risk aversion retards the development process by limiting household incentives to adopt productivityenhancing technologies and to specialize in activities where comparative advantages exist. Such risks also affect the credit-worthiness of rural households and constrain credit markets.

Given the nature of risk for the rural poor, it is quite logical to expect rural households to diversify their sources of income. Recent literature has reemphasized the role of diversification in development. Ellis (1998) argues that diversification in poor rural areas may not be 'a transient phenomenon'. Diversification may be used both under conditions of economic improvement as well as economic decline.

It is intuitive to expect small landowners to have limited opportunities for income from farming. These households use their labour resources in a variety of ways. Working on other farms in the community for either direct income or in-kind payments is common among the rural poor. Even the jobs that do not involve farm work may be directly related to agricultural production in some fashion (e.g. food processing, transportation, or input supply for farming). By the same token the well being of the farming sector can have a direct bearing on jobs that are not tied directly to agriculture.

Since many of the sources of the diversified portfolio of income remain tied to the well being of farming in the community, any shocks that hurt the local agricultural output can place the diversified income of the rural poor in jeopardy. For example, a wide spread natural disaster (drought or flood) that creates significant yield loss for crops and 
damages grassing lands for livestock can have a devastating impact on all sources of income. Thus, even a well-diversified portfolio of income for the rural poor may still be vulnerable to a significant covariate risk - natural disasters.

Consider the effect of a major drought on a poor rural household. First, any crops that are being grown by the household for either household consumption or for sale will be damaged. Further, if the household has livestock, the pasture and other forage sources will also be damaged in a major drought. The household will either be forced to purchase feed, sell the livestock, or move the livestock to a region not impacted by the drought. All of these risk coping strategies will be costly. Mass selling of livestock during a major drought will depress livestock prices. Beyond the commodities grown on the farm, a major drought will also likely hurt the opportunities for selling the household labour to other farmers in the community. For example, opportunities to earn income by selling labour to harvest a crop are generally directly tied to the amount of the harvest.

Since non-agricultural jobs are closely tied to the farm incomes in many communities, a major drought may also affect off-farm job opportunities for the rural poor. Ellis reviews the literature on the multiplier effect of farm income in rural communities. In general these studies suggest that the non-farm economy grows at about the same pace as the farm economy (a US\$ 1 increase in farm economy growth results in a US\$ 1 increase in the non-farm economy growth). Furthermore, after reviewing the literature, Ellis concludes that for many rural areas in developing countries, the rural non-farm sector has little capacity to generate growth on it's own. Agricultural growth and wellbeing are the engines of growth for the non-farm sector in many parts of the world.

When the diversified portfolio of income for the rural poor remains tied to farm production, covariate risk from a widespread natural disaster will still jeopardize the income flows for households even though they have multiple sources of income. Since covariate risks also cause market failure in capital markets and limit the access to credit, there are further general welfare gains that may be tied to efficient systems that can be used to manage natural disaster risk.

\section{$3 \quad$ Mexico as a case study}

Mexico offers an interesting case to examine many of the concepts presented in this paper. Poor small farmers in Mexico primarily use their on-farm agricultural production for household consumption (e.g. food staples such as maize and beans, and livestock products), use little if any improved technologies (e.g. little or no purchased inputs such as improved seeds or fertilizer), and usually depend on a single growing cycle using rain-fed agriculture. In contrast, there are small farmers who might also have small landholdings, but who use improved technologies, are more commercially oriented, and many of whom have access to irrigation and can grow more than one crop per year (and in most cases have other assets, such as good social capital location/infrastructure and institutions).

Another important characteristic of many resource poor small farmers is the relatively low share of on-farm agricultural production in total household income (World Bank, 1996). For small farmers, in general, a significant proportion of total household income comes from off-farm activities. Table 1 summarizes sources of income for Mexican farmers by farm size. 
Table 1

Sources of income by farm size in hectares, 1995

\begin{tabular}{lcccccc}
\hline & Total & $0-2$ & $2-5$ & $5-10$ & $10-18$ & $>18$ \\
\hline Agriculture (\%) & 50 & 22 & 35 & 47 & 55 & 72 \\
Non-agriculture (\%) & 36 & 58 & 50 & 36 & 29 & 24 \\
Remittances (\%) & 14 & 20 & 16 & 17 & 16 & 3 \\
\hline
\end{tabular}

Source: Casco and Rosensweig (2000).

Table 1 shows that for farmers having five hectares or less, only 22-35 per cent of household income comes from agriculture. In contrast, for farmers with over 10 hectares the share of agricultural to total household income ranges between 55-72 per cent. Still, in most cases, own-farm agricultural production is referred to as agricultural production and all other economic activities are referred to as non-agricultural activities. In reality, a major source of income for many small farmers is off-farm agricultural employment (as wage labour for other, usually larger farmers). In addition, there are many economic activities in the rural economy that are closely linked to agricultural production. Thus, small farmers are indirectly dependent on the ups and downs of agricultural incomes (and thus, yield and price risks) faced by medium and large farmers, and risks faced by others in the rural economy.

For small farmers, who use little purchased inputs and self-finance their production, their direct exposure to agriculture (yield or price risk) is relatively low. These small farmers tend to use low risk-low return technologies and cropping patterns to minimize yield losses. And as their marketed surplus tends to be small, their exposure to price risks is rather limited. In fact, it might even be more important for poor small farmers to obtain insurance that reflects agricultural production off their farm - that is commercial agricultural production activities that dominate the rural economy. One of the advantages of weather based index insurance is that it can be designed to compensate for revenue shortfalls for both producers and non-producers in the rural economy. Small farm households in Mexico also tend to have livestock in addition to crops. Here again, insurance that protects against pasture or forage shortfalls due to adverse weather may be important for those having livestock.

Beyond the interesting aspects of small farm agriculture in Mexico, Mexico has two major innovations that have direct bearing on the concepts presented in this paper: 1) the Fondos which are mutual insurance funds whose members are commercially oriented small farmers; and 2) FONDEN (the Fund for Natural Disasters), which is a federal programme that provides ad hoc funds for natural disasters. Both of these institutional arrangements provide opportunities to share covariate natural disaster risk. 
Table 2

Reasons for experiencing an economic crisis

\begin{tabular}{|c|c|c|c|c|c|c|c|}
\hline & \multicolumn{4}{|c|}{ Economic sector } & \multicolumn{3}{|c|}{ Wealth } \\
\hline & All & Farm & Non-farm & $\begin{array}{l}\text { Farm \& } \\
\text { non-farm }\end{array}$ & $\begin{array}{l}\text { Lowest } 2 \\
\text { quartiles }\end{array}$ & $\begin{array}{l}\text { Third } \\
\text { quartile }\end{array}$ & $\begin{array}{l}\text { Fourth } \\
\text { quartile }\end{array}$ \\
\hline $\begin{array}{l}\text { Per cent of } \\
\text { respondents that } \\
\text { faced an economic } \\
\text { crises }\end{array}$ & 59 & 63 & 56 & 60 & 51 & 66 & 66 \\
\hline \multicolumn{8}{|l|}{ Because of } \\
\hline \multicolumn{8}{|l|}{ Low income due to: } \\
\hline Low yields & 23 & 48 & 5 & 22 & 11 & 27 & 27 \\
\hline Low prices & 6 & 11 & 3 & 4 & 4 & 4 & 11 \\
\hline Low sales & 21 & 1 & 34 & 33 & 20 & 21 & 22 \\
\hline $\begin{array}{l}\text { Weak demand for } \\
\text { services }\end{array}$ & 12 & 3 & 18 & 13 & 18 & 8 & 7 \\
\hline $\begin{array}{l}\text { Illness of } \\
\text { entrepreneur }\end{array}$ & 4 & 6 & 3 & 2 & 3 & 7 & 2 \\
\hline Other & 9 & 11 & 9 & 5 & 12 & 6 & 9 \\
\hline Subtotal & 75 & 80 & 72 & 79 & 68 & 73 & 78 \\
\hline \multicolumn{8}{|l|}{$\begin{array}{l}\text { High expenditures } \\
\text { due to: }\end{array}$} \\
\hline $\begin{array}{l}\text { Illness of } \\
\text { entrepreneur or HH } \\
\text { member }\end{array}$ & 18 & 18 & 18 & 17 & 20 & 22 & 15 \\
\hline Other & 7 & 2 & 10 & 4 & 12 & 5 & 7 \\
\hline Subtotal & 25 & 20 & 28 & 21 & 32 & 27 & 22 \\
\hline Total & 100 & 100 & 100 & 100 & 100 & 100 & 100 \\
\hline
\end{tabular}

Note: The survey, conducted in July-August 1994 covered 1,944 rural households in Guanajauto, Puebla, Taumalipas and Veracruz.

Source: World Bank (1995).

\subsection{Sources of income risks faced by small/resource poor farmers in Mexico}

A 1994 survey of rural entrepreneurs (REs) indicated that about 60 per cent of the respondents experienced an 'economic crisis' during the 1989 to 1994 period, with about half of all of these events occurring in 1993 and 1994 (World Bank 1995). The reasons given for experiencing an economic crisis are presented in Table 2.

With respect to the sources of risk, farm REs attributed almost half of the economic crises to low yields, showing the importance of natural disaster risk in these regions of Mexico. Illness of the RE or members of the household were the source of about 20-25 per cent of the reported economic crises - mostly due to unexpected increases in expenditures (as opposed to income losses). For non-farm or mixed farm/non-farm REs, economic crises related directly to low yields were considerably lower. For these REs, about half of the economic crises were attributed to low sales and weak demand for services. 
With respect to the sources of risk for poorer REs, low sales and weak demand for services accounted for about 40 per cent of the economic crises, with only 11 per cent from low yields and about 4 per cent from low prices. This is consistent with the fact that the poorest REs obtain most of their income from non-farm sources and also that they use low yielding, yet hardy, traditional varieties primarily for home consumption. Economic crises attributed to illness of the RE and/or family members were the source of 23 per cent of the crises (more than the total from low yields and low prices). REs in the third and fourth quartiles attributed 27 per cent of the crises to low yields. REs in the fourth quartile reported about 12 per cent of the crises could be attributed to low prices. This is consistent with the profile of wealthier farmers being more exposed to price risks. Thus, traditional crop insurance - even when assuming that it could effectively mitigate income losses from yield shortfalls - could only possibly help small farmers manage one (and perhaps not as significant), of several, sources of income risks.

\subsection{How small farmers in Mexico manage their income risks}

Besides looking at the various sources of income risk, it is also important to assess the risk management strategies and capabilities of small farmers. Unfortunately, the 1994 survey (World Bank 1995) did not report on risk reduction (e.g. diversification) and/or risk mitigation strategies (e.g. crop insurance, savings), but only on risk coping strategies. However, the reported risk coping strategies do shed some light on alternative risk management strategies available to small farmers.

The major risk coping strategies for small farmers were increased labour market participation by the farmer and/or household members (38 per cent), reduced consumption (22 per cent), interest-free loans and/or donations from friends and relatives (15 per cent), sales of assets - notably livestock - (10 per cent) and interestbearing loans from formal or informal sources. Interestingly, only about one per cent of the respondents reported that they delayed repayment of loans (although, only a small proportion had access to formal or informal loans). It was also noted (World Bank 1995) that loans for consumption smoothing were usually received from informal lenders (since formal lenders usually restrict loans to productive purposes), and that interest rates for these informal loans were considerably higher than for formal sector loans, although repayment rates were more flexible and based on the ability to repay. Another, more recent study of rural financial markets (World Bank 2000) indicates that many small farmers resort to a variety of self-insurance strategies that include precautionary savings - primarily using livestock and/or food stocks - along with social capital (e.g. assistance through social networks, including remittances from relatives living outside the area) and, to a much lesser extent, financial assets (e.g. savings). A major problem with holding livestock as a form of savings to be used in times of economic crisis is that many farmers might also be experiencing such a crisis, particularly if it is driven by something like a major drought. If many farmers have the same problem and attempt to sell their livestock at the same time, this can create a covariate risk for livestock prices, as the market is flooded with animals. 


\subsection{Government programmes}

The government of Mexico funds a number of social programmes designed to assist vulnerable rural households. The assistance includes traditional means-tested support programmes, the largest of which is PROGRESA, which provides monetary and in-kind payments to poor rural households for education, health and nutrition. Three programmes, however, are 'event triggered' and relate to parametric insurance. Two programmes involve subsidizing market-based instruments for risk. ASERCA, an agency housed in the Agriculture Ministry provides technical advise and dollar-denominated price insurance for key commodities. A portion of the premium is paid by the government if the insurance does not pay out - that is, if the underlying option is not 'in the money'. A second programme subsidizes the premium on privately provided traditional crop insurance. Until recently, a publicly owned company, AGROASEMEX, sold crop insurance directly in competition with private providers.

In the next section, we examine in more detail the third programme, FONDEN. The programme is a financing scheme in which federal and matching state funds are directed in response to natural disasters. In terms of resources, the programme is largely about financing the repaid repair of public infrastructure - especially roads and bridges. A component of the programme also responds to lost incomes of farmers affected by natural disasters. For example, under the programme, drought or flooding will release funds that states can use to provide direct payments to farmers and to finance temporary programmes like the temporary employment programme, PET, a self-targeting work programme related to improving public infrastructure and soil and forest resources. Because the programme is triggered by natural disasters, it plays a role similar to crop insurance for farming households. A key difference, however, is the FONDEN is event triggered, and therefore, loosely, a parametric triggered instrument. We return to this topic later in the paper.

\section{Public policy alternatives for managing and coping with natural disaster risk}

Generally, and particularly in Mexico, two major courses have been tried that would give individuals the opportunity to manage or cope with natural disaster risk: 1) traditional crop insurance that gives individuals the opportunity to protect against natural disaster risk ex ante; and 2) disaster aid that gives assistance post hoc. There are important differences between these strategies that involve access, incentives, and costs to society. Free disaster aid also can work at cross-purposes with crop insurance by reducing the incentives for individuals to purchase insurance.

\subsection{Problems with traditional insurance}

Government supported crop insurance has been touted for years as being an important innovation for helping rural households manage risk. A market-based, risk-sharing insurance alternative for agriculture has many potential advantages. If society can reduce the risk from growing agricultural commodities, then much of the market failure in supplying credit may be addressed. Crop insurance can be used as collateral for small and medium farmers that would not be able to obtain credit otherwise. These arguments are persuasive since credit plays a major role in development and the linkage between credit and the pace of technological development is well documented. 
Still, there are no examples of successful crop insurance programmes without heavy reliance on government subsidies (Hazell 1992, Skees et al. 1999, Skees 1999b and Skees 2001). Providing individual crop insurance requires significant monitoring and some form of farm level inspection to verify crop losses. Farm level inspection of small plots of land farmed by the rural poor is cost prohibitive for a private firm. Further, public funds to support crop insurance are also questionable since these funds likely have a higher return when used for other purposes. In short, there is a direct negative relationship between farm size and transaction costs in delivering traditional farm level crop insurance that raise serious questions about the social benefits of such efforts.

Traditional crop insurance is always directly tied to a crop. Therefore, one must grow the crop to be eligible for the benefits. Even if crop insurance could be provided with low government costs, crop insurance would be of limited value to the rural poor since income from growing crops is generally a small proportion of the household portfolio. For example, in Mexico only around 20 per cent of the poor rural farm household incomes come from own farm activities (crops and livestock). Paying premiums for crop insurance is even more problematic for the rural poor.

More fundamentally, adverse selection and moral hazard are serious problems in providing traditional crop insurance. This adds to the cost of crop insurance. It also reduces the portion of actual crop value that can be insured since high deductibles or copayments are used as one way to reduce problems of adverse selection and moral hazard. Finally, because of the large covariate risk associated with insuring crop yields, there is a need to use international reinsurers to cover the risk.

Insurance for catastrophic natural disaster risk is in low supply and can become cost prohibitive for the poor for a variety of reasons (Skees and Barnett 1999). Since the risk from insuring natural disasters cannot be pooled (especially in developing countries) the primary insurers rely heavily on traditional reinsurance markets. Reinsurance markets are inefficient, costly, and suffer from pricing cycles that respond to major losses (Froot 1999, Kunreuther et al. 1995, Noonan 1994, Jaffee and Russell 1997, Stipp 1997). Access to reinsurance in developing countries is also limited. Reinsurance can be expensive or impossible in many cases as most reinsurers shy away from providing their services for agricultural risk in developing countries. The international reinsurers that understand agricultural risk rightly conclude that there are problems with underwriting crop insurance in developing countries. They also understand that they can make more money concentrating on the US market that is heavily subsidized.

Finally, decision makers have a cognitive problem in assessing catastrophic risk (Kunreuther and Slovic 1978, Kunreuther 1996). Thus, even when a decision maker may be able to afford the insurance, they may make the wrong assessment about the real risk and decide that the price is too high.

\subsection{Problems with free disaster assistance}

If traditional crop insurance is neither the most appropriate nor affordable means for poor farmers, what else can governments do to assist them manage income risks coming from natural disasters? Free disaster assistance is a common response, even among poor countries, as the international community can be quick to respond when there are natural disasters. However, international aid is more likely in the face of major 
hurricanes and earthquakes and not as forthcoming when the natural disaster is a slowly developing drought. Further, disaster aid is almost always post hoc with few rules and no real knowledge about how much will come and who will get the aid. This raises serious equity questions and opens the door for corruption and abuse.

In many developing countries, the post hoc disaster aid comes in the form of debt forgiveness. Debt forgiveness does not help the poorest rural residents since most of them do not have credit. For that matter, few countries actually have disaster aid programmes that are targeted at the poor. Mexico is an exception as will be developed below.

Economists are rightly concerned with the incentives embedded in free disaster aid (Anderson 1976, Dacy and Kunreuther 1969, Freeman and Kunreuther 1997, Kaplow, Kunreuther 1973, 1993, 1996, Rettger and Boisvert 1979, GAO 1980, 1989). When households grow to expect government compensation for natural disaster losses, they will take on additional risks. If they do not bear the consequences of risky decisions, they will engage in activities that expose them to still more risk. For example, in the US well-intentioned federal relief has likely encouraged further development along geologic fault lines and hurricane prone coastal areas (Noll 1996, Epstein 1996, Rossi et al. 1982). Research by Keeton et al. (1999) suggests that the federal agricultural disaster assistance and heavily subsidized crop insurance encourages crop production in marginal areas. Disaster relief becomes self-perpetuating when individuals don't get proper price signals about their exposure to losses from natural disasters.

To avoid some of the problems with too much free disaster aid, risk must be internalized or at least made explicit. Insurance and other risk sharing markets make risk explicit by pricing risk so that decision makers can fully see the real cost of the risk they face in these markets. Even when free disaster aid is provided, it would be more efficient to make the rules for such aid explicit and to provide it in such a fashion that the expected value of the aid is similar across different regions. Most free aid favours the highest risk regions.

\subsection{Recent innovations for supplying insurance for natural disaster risk}

Recent innovations in the capital markets could provide alternatives for dealing with natural disaster risks. These innovations have potential to make insurance for natural disasters more affordable and more accessible even in developing countries. A convergence of traditional insurance markets and capital markets is underway (Cole and Chiarenza 1999; Doherty 1997, Lamm 1997, Skees 1999a). There are a number of innovations in packaging natural disaster risk into various forms of tradable financial assets. Some of these instruments are packaged as catastrophe bonds; insurance contracts; exotic options; or some other derivative financial instrument, including the advent of an active weather market. In any case, they all provide the holder with large amounts of capital contingent upon the occurrence of some risky event. By purchasing these instruments, those holding the risk share some of their risk exposure with market investors. Those selling the instruments earn favourable returns and are willing to accept the risk as part of a broad-based diversified portfolio. These emerging risksharing markets should increase the supply of risk-sharing solutions for natural disaster risk. 
While risk-sharing markets have been evolving for some time, the development of risksharing instruments based on natural phenomena has escalated rapidly in recent years, largely due to the increase in natural disaster losses suffered by insurers and reinsurers. The result has been a growing market in various types of natural disaster based financial instruments (Doherty 1997, Skees 1999).

One new instrument used in sharing catastrophic risk from natural disasters is the proliferation of catastrophe or 'cat' bonds - bonds whose coupon and principle payments depend on the performance of an index or pool of natural catastrophe risk. There are already successful examples of using cat bonds in Japan and the United States to spread the risks of earthquake insurance, and expansion of this approach offers a unique opportunity to link world financiers and poor people in a partnership that is mutually beneficial. Many of the cat bond transactions where designed as parametric, meaning that their payments would be tied to some statistic where the probability distribution can be estimated and the event can be measured (such as wind speed for hurricanes or the Richter scale for earthquakes). These indexes are of course indirect measures of losses.

In parallel with the development of these financial instruments has been the emergence of an active weather market in the US. Since the utility industry was largely deregulated in 1997, the electricity and natural gas sectors have pioneered markets for temperature based financial instruments. Now that prices for electricity are no longer controlled, the US has witnessed wide swings in prices. For example, in June 1998 the spot market price of electricity increased 214 fold in a matter of days (Dischel 1998).

Suppliers of electricity and natural gas have long known that their revenues and/or costs are highly correlated with temperature. This is even more so today. By using temperature contracts that pay when the temperature is either too cold or too hot, the company can offset losses that are highly correlated with temperature swings. Today temperature-based options are traded both over the counter and on the Chicago Mercantile Exchange. On 1 June 2000, the Wall Street Journal reported that after only three years of existence the temperature market involved US\$ 5.5 billion in trades. A Price WaterHouse survey conducted in May of 2001 shows US\$ 7.5 billion in nominal value for the firms responding.

The weather markets have also spread beyond the US into Europe and Japan. And while temperature for electric utilities remains the primary market, the interest and activity for hedging rainfall events is growing. Such innovation offers potentially affordable insurance for catastrophic risk from droughts and floods. But, even more importantly, as long as the rainfall measures are reliable and secure, the weather market makers are eager to place as many countries into their portfolio as possible, even adding developing countries. This is highly significant since the due diligence for traditional insurance and reinsurance involves high transaction costs that create major hurdles for traditional reinsurers in developing countries.

\section{Using weather based index contracts}

Properly designed weather based index contracts could be used in a variety of ways within a developing country: 
i) as a means of supplying a form of direct insurance for anyone at risk when there major droughts, freezes, or floods.

ii) as a means of facilitating mutual insurance and collective action as with fondos in Mexico;

iii) as a means of providing a form of reinsurance for the private or government agricultural insurance ;

iv) as a mechanism for providing clearly defined disaster aid in a standing disaster relief programme for the rural poor as with the Mexican FONDEN.

The same infrastructure of relatively low cost measures of weather events and the research needed to design effective contracts that match the risk of individuals in the society could be used for each of these purposes as well. The public good of maintaining quality weather data can be enhanced beyond the traditional arguments for why such data are in the public interest. This section uses the experience of Mexico to illustrate the potential applications of weather based index contracts.

\subsection{Using weather index contracts as direct crop insurance}

There is an emerging literature about how rainfall insurance could replace traditional crop insurance (Gautum et al. 1994, Sakurai and Reardon 1997, Skees et al. 1999, Skees 2000). A key advantage of this kind of insurance is that the weather or 'trigger' event (e.g. a rainfall shortage) can be independently verified, and therefore not subject to the same possibilities of manipulation that are present when insurance payments are linked to actual farm losses. And since the contracts and indemnity payments are the same for all buyers per unit of insurance, the usual problems of moral hazard and adverse selection associated with public crop insurance are lessened. Additionally, the insurance would be easy to administer, since there are no individual contracts to write; no on-farm inspections; and no individual loss assessments. This can help make the insurance affordable to a broad range of people, including agricultural traders, shopkeepers and landless workers whose incomes are also affected by the insured events.

Weather index insurance would also be easy to market. For example, it could be sold through banks, farm cooperatives, input suppliers and micro-finance organizations, as well as being sold directly to farmers. Weather insurance is not only for producers and rural people. Banks and rural finance institutions could purchase such insurance to protect their portfolios against defaults caused by severe weather events. Similarly, input suppliers could be the purchasers of such insurance. Once financial institutions can offset the risk with this type of index insurance contracts, they would be in a better position to expand credit to farmers, at perhaps improved terms.

There are yet only few applications of weather-based index insurance in agriculture. There is an insurance plan in Canada in the province of Ontario that uses rainfall indexes and another one in Alberta for corn that uses temperature - heat units. Also, a private insurance company in Argentina is offering a rainfall insurance contract to a milk-producing cooperative (there is strong positive correlation between rainfall and milk yields). While the overall number of applications is still relatively small, the interest is growing. There are several applications of index insurance in agriculture not based on rainfall (or temperature) but on average area yields. Instead of rainfall, the index that triggers the insurance payments is based on estimates of the average yield for 
a county or other predetermined area. Area-based yield insurance has similar benefits as weather-based index insurance as long as there is a reliable assessment of area yields. Some of the countries that have developed agricultural insurance products based on area yields are the US, Sweden, Canada, Brazil, Argentina, and Morocco, the latter still on a pilot basis.

A specially funded project was also awarded to a working group within the World Bank. This project has investigated the feasibility of developing weather based index contracts for four countries: Ethiopia, Morocco, Nicaragua, and Tunisia. Since the project began, several of the professionals involved have begun similar investigations in several other countries, including Argentina, Mexico, Mongolia, Romania and Turkey. There is clearly a growing international interest in weather insurance. Furthermore, the International Finance Corporation (IFC) of the World Bank group is working towards assisting developing countries in having access to the newly developed weather markets. In this role, IFC plans to take a financial interest in these markets, increasing the likelihood of their success.

\subsubsection{Designing a weather index insurance product}

An index contract is very different than traditional crop insurance. Unlike traditional crop insurance where it must be tied to a specific crop with a measure of acreage and yield potential, the index contract can be purchased at any dollar value. Ideally this value would reflect some measure of income at risk to avoid taking on undue risk or giving any appearance of gambling. Since no crop acres must be reported or monitored, the poor household can be provided disaster aid based on the portfolio of income. Anyone can purchase additional index contracts to reflect the full array of income that may be disrupted when for the household when the major drought occurs. For example, if a household earning US\$2,000 per year from a mix of sources estimates that half of this income is vulnerable during a major drought, they may purchase US\$1,000 of value in the drought index insurance. This would be true even if only a very small percentage of the US\$1,000 comes from crops they grow themselves. Traditional crop insurance would never provide such an opportunity. In fact, if the crops they grow themselves were for home consumption, they would not be eligible for any traditional crop insurance.

A number of different contract designs might be considered (Skees 2000). In a straightforward proportional contract the payments would be structured as a percentage of the rain below a specified threshold or strike level. For example, let us assume that the average rainfall is $300 \mathrm{~mm}$ for the three months most critical for the crop season. Any rainfall below $200 \mathrm{~mm}$ creates problems. With a straightforward proportional contract, if rainfall were $100 \mathrm{~mm}$, a 50 per cent payment would be made:

$$
\begin{aligned}
& \text { Percentage payment }=(\text { Strike }- \text { Actual rain }) / \text { Strike } \\
& \text { Percentage payment }=(200-100) / 200 \text { or } 50 \%
\end{aligned}
$$

The protection purchased is an individual decision that should be based on value at risk and the amount of funds that are available to pay premiums. Premiums are a direct function of the protection purchased:

Premium payments $=$ protection purchased $\mathrm{x}$ premium rate 
Indemnity payments are a direct function of the percentage payment and the protection purchased:

Payment $=$ Percentage payment $\mathrm{x}$ protection purchased

For example, with a 50 per cent percentage payment rate, an individual who purchased US\$ 1,000 of protection would receive US\$ 500 (50\% x US\$1,000).

\subsubsection{Preliminary feasibility study for rainfall index contracts in Mexico}

A preliminary study was conducted to assess the feasibility for developing rainfall index contracts in certain areas of Mexico. The methodology and main results of this study are summarized below.

The study examines the development of rainfall contracts to insure against drought during the critical crop growing seasons. The study focuses on four states: Durango, Jalisco, Tamaulipas and Zacatecas. The feasibility study has two main parts. First it examines the correlation between rainfall and yields to determine the loss due to lack of rain. Second, it designs a prototype rainfall contract and examines how this contract affects the variance of revenues from the crops.

To perform the correlation between rainfall and yields, daily rainfall data were collected for stations scattered across these states. For yield data, we used a somewhat subjective procedure to allocate both production and plantings to each municipal for the period 1980-99. To mitigate some potential errors, the decision was made to aggregate the yield data to the DDR level.

Rainfall contracts were designed to reduce the relative risk of the 19 years of trendadjusted yields per hectare for each DDR. Periods for rainfall were selected based on the highest correlation between yields and cumulative rainfall using the time periods for growth to determine most the appropriate periods as well.

The study focuses on proportional rainfall contracts as described above. With rainfall contracts for drought, the payment is based solely on the rainfall event. If crops suffer a serious problem due to freeze, hail or even excess rain, there may be no payments. To make an assessment of how well the rainfall contracts will work, the feasibility study simply assumes that an insured (e.g. a farmer) would purchase a value that would equal the mean yield value within a given DDR. The study then develops an estimate of gross yield for the DDR with no insurance and with rainfall insurance.

Results from this preliminary feasibility study show that for about 40 per cent of the planted area in these four states, rainfall contracts could reduce relative yield risk by up to 30 per cent. These preliminary results suggest that rainfall contracts have potential in Mexico.

\subsection{Using weather insurance to facilitate mutual insurance as with the Mexican fondos}

The introduction of weather index insurance opens numerous possibilities for collective action among small farmers. By removing the covariate risk due to catastrophic weather 
events, this insurance could aid in fostering mutual insurance arrangements among households and also in the effective delivery of financial services to them. For example, informal arrangements between households could reduce transaction costs of sharing risk once covariate risks, such as weather related risks, are reduced or eliminated. Also, micro-finance institutions (MFIs) are becoming important in delivering financial services to the rural poor, but can be victims of natural catastrophes (Nagarajan 1998). Moreover, as Morduch (1999) observes generous donor funds have been key to the role that MFIs have played in providing services after the occurrence of catastrophes but he argues that these donations are unlikely to continue. This increases the important role that natural catastrophic insurance can play in both adding to the services that MFIs provide and in adding to their sustainability in light of a local natural catastrophe. Nagarajan (1998) posed the questions on whether MFIs can develop programmes that could serve as a social safety net following a natural catastrophe and whether they could develop products to manage and mitigate natural catastrophe risks to protect their clients and their portfolio. It can be argued that MFIs could perhaps deliver insurance and natural catastrophe aid to their communities if they (MFIs) have access to catastrophic weather insurance. Black et al. (1999), Skees (1999a) and Zeuli (1999) extend these ideas to the US by arguing that cooperatives could purchase the area based yield insurance and become mutual insures.

Introducing weather insurance to mutual insurance or micro-finance schemes has the additional benefit of dealing with the problem of basis risk. That is the problem that weather events may not have the same impact on all farmers within a region; not everyone has the same loss. This basis risk is perhaps an important problem in the use of weather insurance contracts by individual farmers, particularly small ones. However, it is possible to reduce the basis risk if a group of farmers obtains such insurance and has ex ante arrangements to distribute the payments within the group based upon predetermined criteria. In effect, the group obtains formal insurance to cover systemic and catastrophic risks and relies on informal arrangements to distribute the payments within the group.

A good example of how catastrophic weather insurance could enhance mutual insurance arrangements among farmers can be provided by the Mexican fondos de aseguramiento, or fondos for short. Fondos are groups of farmers formed for the purpose of providing mutual crop insurance to their members. There are about 200 fondos in operation in Mexico having some 70,000 farmers in total as members. They are non-profit, civil associations and they operate in such a way that the collected premiums create reserves to pay indemnities and cover the operational costs. However, in the event of severe weather events, the collected premiums and reserves are not sufficient to cover the losses. This is because natural catastrophes affect all farmers in the fondo simultaneously and their mutual insurance needs to make large payments to all of them at the same time. A World Bank study for the Mexican crop insurance identified drought, excess humidity and frost as the main weather perils that cause catastrophic risks for the fondos. That is, fondos run out of collected premiums and reserves to pay for losses mainly due to these severe weather events. Thus, obtaining insurance for these weather perils is crucial for the financial viability of the fondos. 


\subsection{Using index contracts for disaster funds as with the Mexican FONDEN}

As was established earlier, in countries where the rural poor have been engaged in livelihood diversification, the variety of income sources may still be exposed to risks from major natural disasters. Not only can the own farm income suffer, but the opportunities to earn a wage in various activities that are directly tied to agriculture will also become limited. Further, the link connecting the non-farm economy to the farm economy may also mean that non-farm job opportunities suffer as well during a regional natural disaster. For these reasons, tying a standing disaster aid package directly to weather events may be the most reasonable and clear way to provide assistance to the rural poor during a natural disaster.

How would a weather based index catastrophe aid programme work? The first item to consider is designing a contract that would provide roughly equal aid to all low-income households regardless of the regional location. It should not be designed to replace only a portion of the lost income. Finding the right weather events that create the most serious losses requires some research.

The value of free aid can be calculated using the same method as one would use if the weather index were being developed as insurance. These calculations can be used to provide the same implicit value of aid regardless of the large differences that may exist among different regions within a country. This is important as most disaster aid rarely does that, thus creating perverse incentives for risk taking.

A logical threshold may be to provide aid for infrequent events, say, 1 in 20 or more year events. Using a parametric weather trigger to make disaster payments makes the rules explicit and transparent. It also should improve the timing of payments. Even more important, such indexes could facilitate an insurance market in weather contracts. The government would now have the incentives to maintain a reliable infrastructure to measure the important weather events. Further, there would have been some level of research performed by the government to perform the analysis needed to establish the parameters for contracts that transfer the same amount to everyone. Private companies could do any number of things with the information and infrastructure; they could match the contract of the government with more money; they could offer a layer of insurance above what the government offers (i.e., for less frequent events); they could both match and offer another layer. The key is that a disaster programme that is structured in this fashion would not crowd out private sector innovations rather it would encourage it.

\subsubsection{The Mexican FONDEN}

The Fund for Natural Disasters (FONDEN) was established in 1996 within the Ministry of Finance as a last resort source of post-disaster financing inter alia for reconstruction of public infrastructure, and compensation to low income producers for crop and livestock losses arising from natural disasters. In terms of expenditures, FONDEN's coverage of public infrastructure is much larger than its coverage of crop and livestock losses.

FONDEN is a disaster relief programme rather than an insurance programme; however, the agricultural component of the programme has characteristics similar to privately provided crop insurance. For example, FONDEN makes payments in response to many of 
the same perils covered by private insurers - for example, wind, drought and frost. In addition, claims of loss trigger field inspections as do claims to crop insurers in Mexico.

There are key differences between FONDEN and private insurance, however. FONDEN payments are triggered only when droughts, frost or other perils affect most producers in a region - that is, FONDEN only pays out against systemic risks. Thus, individual farmers who lose their crops due to idiosyncratic risks are unprotected. Moreover, payments from FONDEN are made only after the declaration of a disaster by the federal government following a formal request from the State Governor or head of a federal Ministry, after a potentially conflictive loss adjustment process has been completed and agreed to by an inter-secretarial committee, and after state or municipal co-participation payments have been made to state trust funds. This is a time-consuming and potentially conflictive process, despite the guidance provided by FONDEN's rules. Indeed, at times it may take 5-6 months for FONDEN payments to actually be made to state trust funds, thereby engendering liquidity problems and complaints at the state level.

\subsubsection{How well does FONDEN protect smallholders?}

Only smallholders are eligible to receive FONDEN payments; however, the definition of smallholder varies according to regional and agronomic differences. Eligibility requirements range from five or fewer hectares to twenty and fewer hectares depending on state. FONDEN also restricts the number of hectares eligible for payments in order to limit payments to any one farmer. In addition, irrigated land and insured lands are not eligible for FONDEN payments. Payments vary with type of crop. Maximum payments and area limits are reported in Table 3.

Payments for agricultural losses from FONDEN from 1997-99; totaled nearly one billion pesos for the three-year period. Generally, the FONDEN payments were spread out among many states, with no single state accumulating more than 6 per cent of total pay outs. The exceptions are Puebla with 9 per cent of total payouts and Oaxaca with 14 per cent.

Table 3

Limits on FONDEN payouts

\begin{tabular}{lll}
\hline Crop & $\begin{array}{l}\text { Maximum payment per hectare } \\
\text { (pesos) }\end{array}$ & Maximum area \\
\hline Annual crops & 281 & 5 hectares \\
Coffee & 315 & 3 hectares \\
Fruit and other perennial crops & 782 & 2 hectares \\
Nopal (cactus) plantations & 281 & 3 hectares \\
Tropical forest & 731 & 5 hectares \\
Temperate forest & 731 & 10 hectares \\
Livestock & Maximum payment per head & Maximum number \\
Cattle & 197 & 25 \\
\hline
\end{tabular}

Source: SHCP 
When maximum FONDEN payments are made, analysis shows that they are likely to cover a significant portion of the investment smallholders have made in the lost crop. Using sample data from the 1996 ejido survey, average production costs were calculated for producers owning five or less hectares. The costs and revenue were then adjusted for inflation and compared to the maximum FONDEN payment of 281 pesos per hectare for annual crops. On average, FONDEN payments cover nearly 80 per cent of the irreversible investments farmers make in inputs and labour when planting their crops. There are wide regional differences, however, depending upon the level of inputs commonly used - that is, the crop-investments of farmers who use low-input techniques are better protected by FONDEN than the crop-investments of farmers using more costly ones.

Looking at the revenue side, regional differences emerge as well. However, the analysis shows that in no region do FONDEN payments compensate farmers for lost income covering on average only eight per cent of expected revenue.

\subsubsection{What is the market value of FONDEN coverage?}

As already mentioned, FONDEN payments are triggered through a discretionary process, and for this reason it is difficult to determine the likelihood of a FONDEN payout. However, setting aside political uncertainties, FONDEN guidelines provide strict definitions of certain types of perils. These guidelines are summarized in Table 4 .

For perils such as drought and frost, the guidelines are similar to the types of triggers found in parametric insurance. Unlike regular crop insurance, parametric insurance does not directly compensate for assessed losses, but rather pays out when an agreed upon indicator meets an agreed upon condition - for example when the temperature recorded at a defined weather station falls below a certain level. Consequently, transaction costs associated with the insurance are lower since field assessments of damage are not required. Parametric insurance is also easier to price, since the expected payouts from the insurance can be estimated by calculating from historic data the probability of the trigger condition being met.

Table 4

Guidelines for selected operations of FONDEN.

\begin{tabular}{|c|c|c|}
\hline Hazard & Activity & Trigger \\
\hline \multirow[t]{2}{*}{ Drought } & Livestock & $\begin{array}{l}\text { Two consecutive months of average rainfall below either } 50 \text { per } \\
\text { cent of its historical average or its historical minimum. }\end{array}$ \\
\hline & Crops & $\begin{array}{l}\text { As above, but for any period of time during which damages may } \\
\text { occur. }\end{array}$ \\
\hline \multirow[t]{4}{*}{ Frost } & Horticulture & $\begin{array}{l}\text { Minimum temperatures. Beans 3. Potato }-2 \text {, Tomato } 0 \text {, } \\
\text { Watermelon } 3 \text {, Cabbage } 0 \text {, Melon }-1 \text {. }\end{array}$ \\
\hline & Fruits & Minimum temperatures. Apple -34, Orange -2, Peach -26. \\
\hline & Grains & $\begin{array}{l}\text { Minimum temperatures. Corn } 0-5 \text {, Sorghum }-6 \text {, Wheat }-9 \text {, } \\
\text { Oats }-8 \text {. }\end{array}$ \\
\hline & Fibers & Minimum temperatures. Cotton -1 . \\
\hline Hail and snow & Any & $\begin{array}{l}\text { Not specified. In general, an unusual occurrence is defined as } \\
\text { event that is below one standard deviation of its historical } \\
\text { average. }\end{array}$ \\
\hline
\end{tabular}

Source: Diario Oficial de la Federación, 29 February 2000. 
FONDEN rules state that livestock owners are eligible for drought payouts when cumulative rainfall is below either 50 per cent of its historical average or historical minimum for two consecutive months (any combination of the two events is allowed); small crop producers are eligible when rainfall is below these thresholds for a period of time judged to be sufficient to have generated permanent damages to the crops. Although this common rule would apply to all states, the variance in rainfall differs among states and consequently the probability of drought, as defined by FONDEN rules, will differ among states as well.

FONDEN does not only payout for drought but also for flooding, for excess rains and for other calamities. When calculating the value of FONDEN to smallholders, each peril covered adds to the probability that FONDEN payments will be triggered. Calculating this number precisely is impossible; since not all perils are defined parametrically by FONDEN rules. However, this general point is illustrated for two parametrically triggered insurances: drought and frost. As with drought, frost is strictly defined by FONDEN rules. A frost is said to occur when temperatures fall below a defined temperature during critical growing months. In turn, critical growing months will differ by crop. Consequently, probabilities associated with the frost trigger will differ by state and by crop. Moreover, payment levels differ among field crops and horticultural crops.

\subsubsection{Implications for smallholders}

Although the rules for drought and frost are reasonable and technically well defined, the analysis above shows that the rules result in differing levels of coverage for different regions. Drought protection is greater in areas where the variance of rainfall is greater and frost coverage is greater for colder climates and for crops whose growing seasons makes them most susceptible to frost. Consequently, the FONDEN rules unintentionally reward risky behaviour. Such perverse incentives can be easily changed by rewriting FONDEN rules so that payouts are given equal probability across regions. For example, using historic weather data, define drought as occurring when the rainfall for two consecutive months falls below a trigger defined as having a 10 per cent probability of occurring.

The rule that makes smallholders who purchase private insurance ineligible for FONDEN payments also unintentionally encourages smallholders to take on more risk. For example, often crop insurance is a precondition for participation. In addition, price insurance is frequently required as well. The practice facilitates credit, and also helps protect variability in farm income. However, smallholders who participate lose FONDEN eligibility - a loss that may make alternative methods of risk management less attractive.

\subsubsection{Comparisons with parametric insurance}

As already discussed, the parameters for drought are well defined within the FONDEN rules, but there is room for discretion in the application of the rules. Having a measure of the cost of discretion can provide insights into how FONDEN functions. Unfortunately, the task of calculating the discretionary component of FONDEN is hampered by a number of difficulties. Nonetheless, we provide below a partial comparison, based on estimated and recent historic payments for drought. 
In making the comparison, it is worth noting that the Ministry of Agriculture (SAGARPA) is only one of three agencies that make payments related to drought. Here we are only able to compare the amount payable by SAGARPA for crop damage. We find that the historic FONDEN crop related payouts for drought are in line, but slightly below, rough estimates based on probabilities. This may mean that current FONDEN criteria are triggered too frequently and that the discretionary component of FONDEN has worked to limit expenses. However, it also shows that parametric triggers can generate similar payments. This finding is relevant for all programmes, since parametric triggers could be used for social protection expenditures that are additional to payments for croprelated losses.

\subsubsection{Are there benefits to parametric triggers for FONDEN?}

If suitable triggers can be found, there are several good technical reasons for converting to a scheme that pays out based solely on parametric triggers. First, triggers can be derived that provide equal protection to all smallholders. Second, reinsurance becomes straightforward, since payouts are based on historic probabilities that reinsurers can easily understand and price. Third, the process is quick and low cost since field visits are not required.

As discussed in the previous section, current rules provide varying levels of protection as measured by the probability of a payout - among farmers growing different products and among farmers growing the same products in different states. Consequently, the programme protects some farmers more than others. Designing triggers that have an equal probability of payout regardless of crop type or location would eliminate this distortion. In addition, because compensation depends on crop damage - as measured by field inspectors - farmers who take preventative action to limit crop losses are penalized. In contrast, payouts based solely on weather conditions would restore normal incentives to take preventative action. Of course, any free insurance distorts by providing marginal compensation without cost. This can also be reduced by designing the triggers so that the payout is only for rare events.

If short-term budget issues can be solved, there are often advantages for governments who self-insure. However, in the case of Mexico, state governments have been especially hard pressed to meet recent requirements for matching (70/30) funds. Purchasing reinsurance from private firms converts large lump-sum expenditures into annual premiums that can be more easily budgeted. Doing so, however, will come at a price, which in turn, is related to the probability of payouts. For parametric insurance these costs can be calculated in a straightforward way. In contrast, when payouts include a measure of discretion, reinsurers will have difficulty pricing the probability of payouts and may be reluctant to reinsure.

Because field visits are not required, the administrative costs to FONDEN should fall if parametric insurance is adopted. For this report, we did not have administration costs for FONDEN and this perhaps should be the subject of a further investigation.

Breaking the link between payouts and field inspections has a cost as well. The most significant drawback of parametric triggers is the potential mismatch between conditions at weather stations and effects in the field. This basis risk has an analogy with price hedging where local prices may differ from price observed in Chicago or other hedging markets. Whether the basis risk overwhelms the significant benefits of 
parametric insurance is an empirical question, depending largely upon the spatial correlation of rainfall events over time. For example, in areas with micro climates, the spatial correlation may be too weak and the basis risk too high.

\section{Summary and conclusions}

A host of risks face poor rural households in developing countries. Social programmes are needed to address health risk, human capital development risk, and natural disaster risk. Among the more popular risk management strategies used by poor rural households is diversification. However, diversification as a risk management strategy can hinder development since gains are possible when households specialize. Further, since farming remains a dominant activity in many rural areas, diversification may not actually spread certain types of risk, in particular, weather events that cause widespread loss for crops and grazing lands. These covariate risks may impact a variety of sources of income: own farm, agricultural labour, and non-farm income. In some rural areas, even the non-farm jobs can be tied to the well-being of the local farm economy. Any natural disaster or general downturn in producer prices that hurts the local farm economy may have negative effects on non-farm jobs as well.

If there are no mechanisms available to help households manage natural disaster risk or price risk then financial markets will likely be incomplete. Such incomplete markets will likely mean that inadequate credit is available in the rural economy. If farmers either have no access to credit or exhibit extreme risk aversion and do not borrow, they are unlikely to adopt available technologies that are needed to advance agricultural production. Thus, efforts that combine the dual roles of helping the rural poor recover from natural disasters and aid in the emergence of market based risk management strategies are important. However, public disaster assistance is problematic as it can send the wrong signals to those in high-risk areas.

With these issues in mind, this paper focuses on natural disaster risk policies. Traditional crop insurance is dismissed as a viable alternative for medium and small farmers in developing countries. Given recent developments in international capital markets we turn to the potential of indexing weather events (e.g. shortfalls or excess rain, extreme temperatures, etc.). While there is no single solution, such indexes could facilitate multiple objectives: 1) they could be used as an objective means of providing disaster aid based on relative risk so as not to favour high risk regions; 2) they could be used by state governments to fund disaster aid; 3) they could be used by intermediaries in the economy to help manage natural disaster risk; and 4) they could be used directly as insurance to households against certain local natural disasters.

Once governments decide to use weather index contracts, any combination of uses becomes possible. The public support of a sound and secure infrastructure to measure weather events is a prerequisite for many of the items discussed above. Governments in developing economies, with the aid of international development agencies, can also process and make historical weather data publicly available. To the extent that the capital markets trust the data for weather events in developing countries, it may be possible someday to create efficient and affordable risk sharing instruments that can be used for multiple purposes. 


\section{Bibliography}

Agroasemex (2000a), Diez Años de Seguro Agropecuario en México: Memoria 19902000. AGROASEMEX. Santiago de Querétaro, México.

AGROASEMEX (2000b), Normas y Procedimientos de Operación que Deberan Observar los Fondos de Aseguramiento que Contraten el Reaseguro Ganadero con Agroasemex, S.A. AGROASEMEX, Santiago de Querétaro, México.

Anderson, D.R. (1976), 'All Risks Rating Within a Catastrophe Insurance System', Journal of Risk and Insurance, 43: 629-51.

Black, J. Roy, Barry J. Barnett, and Yingyao Hu. December (1999), 'Cooperatives and Capital Markets: The Case of Minnesota-Dakota Sugar Cooperatives', American Journal of Agricultural Economics, 81: 1,240-6.

Casco, A. and A. Rosenzweig (2000), 'La Politica Sectoral Agropecuaria En Mexico: Balance de una Decada', IICA, Mexico.

Cole, Joseph B. and Anthony Chiarenza (1999), 'Convergence in the Markets for Insurance Risk and Capital', Risk Magazine, July, pp.9-12.

Cord, L. (2001), 'Rural Safety Nets Lessons from Experience', World Bank, Washington DC, Draft, February.

Dacy, D.C. and H. Kunreuther (1969), 'The Economics of Natural Disasters: Implications for Federal Policy', New York, The Free Press.

Dawson, P.J. (1988), 'Labour on the Family Farm: A Theory Under Uncertainty. Agricultural Economics', 1: 365-80, Elsevier Science Publishers B.V., Amsterdam.

Dischel, Robert (1998), 'The Fledgling Weather Market Takes Off', Applied Derivatives Trading, November, Focus, www.adtrading.com

Doherty, N.A. (1997), 'Financial Innovation in The Management of Catastrophic Risk', Presented paper at ASTIN/AFIR Conference, Australia, August.

Ellis, Frank (1998), 'Household Strategies and Rural Livelihood Diversification'. The Journal of Development Studies.

Epstein, R.A. (1996), 'Catastrophic Responses to Catastrophic Risks', Journal of Risk and Uncertainty, 12: 287-308.

Freeman, P.K. and H. Kunreuther (1997), 'Managing Environmental Risk Through Insurance', Boston MA, Kluwer Academic Press.

Froot, Kenneth A. (1999), 'The Financing of Catastrophic Risk. Chicago and London', The University of Chicago Press.

Gautum, M., P. Hazell and H. Alderman (1994), 'Rural Demand for Drought Insurance', Policy Research Working Paper, No.1,383, November.

Hazell, Peter B.R. (1992), 'The Appropriate Role of Agricultural Insurance in Developing Countries', Journal of International Development, 4: 567-81.

Jaffee, D.M. and T. Russell (1997), 'Catastrophe Insurance, Capital Markets, and Uninsurable Risks', Journal of Risk and Insurance, 64: 205-30. 
Kaplow, L. (1991), 'Incentives and Government Relief for Risk', Journal of Risk and Uncertainty, 4: 167-75.

Keeton, Kara, Jerry Skees and James Long (1999), 'The Potential Influence of Risk Management Programs on Cropping Decisions', Selected paper at the American Agricultural Economics Association meetings, Nashville, TN, 8-11 August.

Kunreuther, H. (1973), 'Recovery From Natural Disasters: Insurance or Federal Aid?', Washington DC, American Enterprise Institute for Public Policy Research.

Kunreuther, H. (1993), 'Combining Insurance with Hazard Mitigation to Reduce Disaster Losses', Natural Hazards Observer, 17: 1-3.

Kunreuther, H. (1996) 'Mitigating Disaster Losses through Insurance', Journal of Risk and Uncertainty, 12: 171-87.

Kunreuther, H., J. Meszarous, R. Hogarth, and M. Spranca (1995), 'Ambiguity and Underwriter Decision Processes', Journal of Economic Behavior and Organization, 26: 337-52.

Kunreuther, H. and P. Slovic (1978), 'Economics, Psychology, and Protective Behavior', American Economic Review, 68: 64-9.

Lamm, R.M. Jr. (1997), 'The Catastrophe Reinsurance Market: Gyrations and Innovations amid Major Structural Transformation', Bankers Trust Research. Bankers Trust Company, New York, 3 February, pp. 1-13.

Morduch, J. (1999), 'The Microfinance Promise', Journal of Economic Literature, xxxviii: $1,569-614$.

Nagarajan, G. (1998), 'Microfinance in the Wake of Natural Disasters: Challenges and Opportunities', Development Alternatives, Inc.

Noll, R.G. (1996), 'The Complex Politics of Catastrophe Economics', Journal of Risk and Uncertainty, 12: 141-6.

Noonan, B. (1994), 'A Catastrophe Waiting to Happen?' Best's Rev., February, pp. 30-3.

Rettger, M.J. and R.N. Boisvert (1979), 'Flood Insurance or Disaster Loans, An Economic Evaluation', American Journal of Agricultural Econmics, 61: 496-505.

Rossi, P., J. Wright and E. Weber-Burdin (1982), 'Natural Hazards and Public Choice: The State and Local Politics of Hazard Mitigation', New York, Academic Press.

Sakurai, T. and T. Reardon (1997), 'Potential Demand for Drought Insurance in Burkina Faso and its Determinants', AJAE, Vol.79: 1,193-207.

Siegel, P.B. and J. Alwang (1999), 'An Asset Based Approach to Social Risk Management: A Conceptual Approach', Social Protection Discussion Paper No.9,926, World Bank, Washington DC, www.worldbank.org/sp

Skees, Jerry R (1999a), 'Opportunities for Improved Efficiency in Risk-Sharing Using Capital Markets', American Journal of Agricultural Economics, 81: 1,228-33.

Skees, Jerry R. (1999b), 'Agricultural Risk Management or Income Enhancement?' Regulation, The CATO Review of Business and Government, 22: 35-43. 
Skees, Jerry R. (2000), 'A Role for Capital Markets in Natural Disasters: A Piece of the Food Security Puzzle', Food Policy, 25: 365-78.

Skees, Jerry R. (2001), 'The Bad Harvest', Regulation, The CATO Review of Business and Government, 24: 16-21.

Skees, Jerry R. and Barry J. Barnett (1999), 'Conceptual and Practical Considerations for Sharing Catastrophic/Systemic Risks', Review of Agricultural Economics, 21: 424-41.

Skees, J., P. Hazell, and M. Miranda (1999), 'New Approaches to Crop Insurance in Developing Countries', EPTD Discussion Paper No.55, International Food Policy Research Institute, Washington DC, November.

Stipp, D. (1997), 'A New Way to Bet on Disasters', Fortune, 8 September.

US General Accounting Office (1998), 'Disaster Assistance: Crop Insurance Can Provide Assistance More Effectively than Other Programs', RCED-89-211, Washington DC, US Government Printing Office.

US General Accounting Office (1980), 'Federal Disaster Assistance: What Should the Policy be?' PAD-80-39, Washington DC, US Government Printing Office.

World Bank (1995), 'Mexico: Rural Financial Markets', World Bank, Washington DC, Report No.14599-ME.

World Bank (1996), 'Mexico Rural Poverty', World Bank, Washington DC, Draft, 30 September.

World Bank (2000), Mexico Rural Finance, Savings Mobilization Potential and Deposit Instruments in Marginal Areas', World Bank, Washington DC, August 31.

Zeuli, Kimberly (1999), 'New Risk Management Strategies for Agricultural Cooperatives', American Journal of Agricultural Economics, 81: 1,234-39. 